\title{
Perceptions of Assistant Principals' and Principals' of Bahrain Government Schools about the Impact of the Bahrain Teachers College Educational Leadership Program on Their Performance
}

\section{Faten S. M. Abdel-Hameed, Osama AlMahdi, Abdelbaky Abouzeid, Hasan Al-Wadi, Mahmoud Osama Jalal, Moosa Fateel, and Salman Yousuf Bahrain Teachers College, University of Bahrain, Manama, Kingdom of Bahrain}

\section{Abstract}

This article examines the perceptions of school assistant principals and principals who completed the Bahrain Teachers College higher diploma of education leadership program about its impact on their performance. The study sample consisted of

Corresponding Author: Faten S. M. Abdel-Hameed fmahmoud@uob.edu.bh

Received: 18 September 2018 Accepted: 10 October 2018 Published: 15 October 2018

Publishing services provided by Knowledge E

(c) Faten S. M. Abdel-Hameed et al. This article is distributed under the terms of the Creative Commons Attribution License, which permits unrestricted use and redistribution provided that the original author and source are credited.

Selection and Peer-review under the responsibility of the Sustainability and Resilience Conference Committee. 141 program graduates from 9- cohorts. A multilevel concept in measuring the impact of the educational leadership program on the graduates' performance was employed. The framework consisted of 4 levels: self-learning, changing others, embedding changes in school practices and sustainability of change and scaling up the school performance. The study questionnaire was designed on the basis of this framework. Results show that the Educational Leadership program positively affected its graduates' performance in the 4 levels. The majority of the program graduates agreed that the program positively affected their personal qualities, leadership styles and practices to support school development, school staff, students' performance and school ranking. The majority of the program graduates also agreed that the program positively affected their skills in dealing with curriculum innovations, professional development, research, strategic planning, staff appraisal, communication with community, using ICT, improving students' learning and applying educational ethics.

Keywords: Education Leadership, School Principals' Performance, Leadership Styles, School Practices, Leadership Skills

\section{S OPEN ACCESS}




\section{Introduction}

This article addresses the perceptions and practices of the assistant principals and principals in Bahrain government schools about the impact of the Educational Leadership Program (ELP) offered by the Bahrain Teachers College (BTC) on the performance of their roles and responsibilities in schools. It aims at finding out to what extent have school leaders' personal qualities, leadership styles, and knowledge and practices changed after completing the BTC higher diploma of education leadership program.

The Educational Leadership Program has been offered, since 2008, through Bahrain Teachers College to train the assistant principals and principals in the Bahraini public schools. Since the implementation of the program, there has been no thorough evaluation of its impact on school leaders and their respective schools' performance. Such information will help BTC to revise the program requirements for the purpose of improvement and alignment with the school leaders' needs, the Ministry of Education's expectations, and international best practices.

The Education Leadership Program offered by BTC covers 10 topics, namely; curriculum innovations, professional development, educational research, strategic management, staff appraisal, communication with community, home-school relations, using ICT, improving students' learning and applying educational ethics.

\section{Literature Review}

The quality of a school leader influences instruction inside the classroom and plays a key role in improving students' achievement and school improvement (Barber, Whelan, \& Clark, 2010). Therefore, it is essential to prepare school leaders to implement and sustain improvement and change in schools for the success of the educational reform processes. Researchers have emphasized the importance of school leaders as key factors in developing teachers' performance and supporting students' learning and success (Leithwood \& Duke, 1999 and Leithwood et al., 2004). The rapidly changing social, economic and political contexts indicate that educational systems should adapt its current practices and approaches to redefine school leaders' roles, responsibilities and the way these leaders are being prepared and trained to face such challenges (Pont, Nusche, \& Hopkins, 2008).

Various studies provided a list of practices and characteristics of effective school leaders. A large-scale study across different school systems by Barber, Whelan and 
Clark (2010) highlighted a common set of beliefs, attitudes, and personal characteristics which effective leaders possess. These beliefs and characteristics include: a major focus on students' academic outcomes, being adaptable to context and people, developing self-awareness and being able to learn, willing to take risks and challenging existing orthodoxies and behaviours and finally being optimistic and enthusiastic. In addition, Marzano, Waters, \& McNulty (2005) developed a list of 21 categories of responsibilities of school leaders that are related to students' achievements. Cotton (2003) described 26 behaviours of principals of high achieving schools; of which were the importance of shared leadership and focusing on instruction. Williams (2009) used a pre-post design to study how principal interns acquired skills to improve student learning. He found that "values, knowledge, and performance have long been recognized as essential constructs for school effectiveness". Accordingly, common expectations for leadership preparation programs are to provide real-world practice in real school settings and to equip school leaders with such common effective characteristics, skills, attitudes and dispositions.

Modern school leaders are required to play roles that would result in improving students' achievements, through engaging in building visions, implementing organizational reform and change, leading instruction, curriculum and assessment development, analysing budgets, facilitating managing and administrating special programs, making resource-allocation decisions, and building school-community relations (Davis, Darling-Hammond, LaPointe, \& Meyerson, 2005; Silins et al., 2003 and Leithwood and Jantzi's, 2006). Therefore, a growing focus in many countries around the world on the development of appropriate preparation and training programs for school leaders to meet the complex needs of schools and the wider education system has been taking place (Bush, Briggs, \& Middlewood, 2006). In addition, many educational systems around the world have realized that in order to increase the professionalism of its school leaders' new programs should be developed instead of relying only on those leaders' natural abilities and experiences (Nicolaidou \& Petridou, 2011). That is to say, comprehensive and systematic preparation training, rather than inadvertent experience, is key to produce effective school leaders (Bush, 2009).

However, it has been found that not all these preparation programs would produce more effective school leaders and some of these programs fail to equip those leaders with the necessary skills to fulfil their expected roles (Darling-Hammond et al., 2007). Bush (2009) argued that in order to measure the impact of school leadership programs, there should be an examination of whether those programs are producing effective 
leaders or not. Therefore, there has been growing tendency to evaluate the impact and effectiveness of school leaders' programs and its practices (Fluckiger, Lovett \& Dempster, 2014).

There have been many attempts to respond to this need around the world, however, no such attempt was made in Bahrain to measure the impact of ELP program, which is the only program of its kind in the Kingdom. This study is an attempt to understand what is currently happening in the educational leadership in the Bahraini context, as this is the first step to diagnosing and empirically documenting practices that are in place. It also aims at measuring the acquired educational leaders' knowledge, skills and values (dispositions) of the BTC-Higher Diploma of Educational Leadership program graduates as related to promoting the success of all students.

\section{Conceptual Framework}

A multilevel concept was developed and applied in measuring the impact of the educational leadership program on its graduates' performance. The framework consisted of 4-levels, namely: self-learning, changing others, embedding changes in school practices, and sustainability of change and scaling up the school performance.

Level-1 of the program impact (first assumption) is concerned with the change in knowledge, skills, attitudes and dispositions of school leaders after completing the program. According to Osterman \& Hafner (2009), Barton, L.T. (2013) and Yan \& Ehrich (2009), preparation of knowledgeable and skilful leaders is essential. The second key assumption (level-2 of the program impact) concentrates on the extent to which level1 impact is transferred to school \& classroom practices both qualitatively and quantitatively. This is supported by Davis, Darling-Hammond, LaPointe, \& Meyerson (2005); Silins et al. (2003); and Leithwood and Jantzi's (2006). Level-3 of the program impact (third assumption) focuses on the extent to which level-1 \& level-2 impacts are assimilated into the school routines \& culture. Preparing school leaders to develop and deal with school routines have been emphasized by Darling-Hammond el al. (2010) and Fullan (2007). The fourth assumption of the study (level-4 of the program impact) emphasizes the sustainability of the impact and scaling up of students' achievements and school performance. Many researchers related the effectiveness of leaders' preparation programs to students' and school achievements (Marzano, Waters, \& McNulty, 2005; Cotton, 2003). 


\section{Research Methodology}

\subsection{The study sample}

This study employed a quantitative research design. The research data was gathered by using a 108 items self-report questionnaire developed and designed on the basis of a 4 -level conceptual framework (self-learning, changing others, embedding changes in school practices and sustainability of change and scaling up the school performance). The questionnaire was administered to a sample of school principals and assistant principals' who graduated from the Educational Leadership Program offered by Bahrain Teachers' College, University of Bahrain. The 108 items questionnaire has the reliability coefficient of 0.988 which is considered a high reliability.

The questionnaire was distributed to 270 school principals and assistant principals, 141 of them responded and the total number of valid questionnaires was 116 which equals $43 \%$ of the distributed questionnaires. The sample included graduates of nine cohorts of the Educational Leadership Program - the academic years 2008-2009 to 2016-17. Most of the respondents were graduates of the academic years 2012 to 2016.

\subsection{The research questions}

The following are the study research questions:

1. What are the principals' perceptions of their personal qualities after completing the education leadership program at BTC?

2. What are the principals' perceptions of the change in their leadership styles and practices to support their school development after completing the education leadership program at BTC?

3. What are the principals' perceptions of the extent to which their knowledge $\&$ practices changed (self-learning) after completing the education leadership program at BTC?

4. What are the principals' perceptions of the extent to which their knowledge $\&$ practices changes after completing the education leadership program at BTC affected their staff teaching and practices (changing others)? 
5. What are the principals' perceptions of the extent to which their knowledge $\&$ practices changes after completing the education leadership program at BTC are embedded in their schools' routine (embedding changes in school practices)?

6. What are the principals' perceptions of the extent to which their knowledge \& practices changes after completing the education leadership program at BTC affected their students' performance and school ranking (sustainability of change and scaling up the school performance)?

7. What are the principals' perceptions of the extent to which their curriculum innovation, professional development, research, strategic management, staff appraisal, school community communication, home-school relations, using ICT, improving students' learning and applying educational ethics skills are affected after completing the education leadership program at BTC?

\section{Findings of the Research}

The obtained data were analysed using SPSS. Results are illustrated in the following tables according to the order of the research questions stated above.

To answer Question (1) of the study: What are the principals' perceptions of their personal qualities after completing the education leadership program at BTC?, the mean, standard deviation, percent and ranking of the study sample's responses to the impact of the program on the principals' personal qualities were calculated. Table 1 summarizes the obtained results.

Table 1 shows that $83.8 \%$ of the sample considers their study in the program positively affected their personal qualities, with item 12 (I am better at listening to others) ranked highest, while item 7 (I am more willing to take risks) ranked lowest.

To answer Question (2) of the study: What are the principals' perceptions of the change in their leadership styles and practices to support their school development after completing the education leadership program at BTC?, the mean, standard deviation, percent and ranking of the study sample's responses to the impact of the program on the principals' leadership styles and practices to support their school development were calculated. Table 2 summarizes the obtained results.

Table 2 shows that $85.9 \%$ of the sample considers their study in the program positively affected their leadership styles and practices to support school development, with item 34 (I encourage my staff to express their viewpoints openly) ranked highest, 
TABle 1: Descriptive statistics for Principals' Perceptions of Personal Qualities.

\begin{tabular}{|c|c|c|c|c|}
\hline No. & Items & Mean & Std. D & Percent \\
\hline 1 & I have higher intellectual capacity & 4.12 & 0.69 & 82.43 \\
\hline 2 & I am more objective in my judgment & 4.16 & 0.63 & 83.13 \\
\hline 3 & I have higher ability to control my emotions well at work & 4.25 & 0.67 & 85.00 \\
\hline 4 & I am more optimistic during challenging times & 4.22 & 0.65 & 84.48 \\
\hline 5 & I am a better innovative thinker & 4.12 & 0.63 & 82.41 \\
\hline 6 & I have higher ability to manage my time well at work & 4.10 & 0.61 & 81.91 \\
\hline 7 & I am more willing to take risks & 3.98 & 0.69 & 79.66 \\
\hline 8 & I am better at problem solving & 4.17 & 0.62 & 83.45 \\
\hline 9 & I am more focused on achieving school goals & $4 \cdot 34$ & 0.56 & 86.72 \\
\hline 10 & I have better understanding of people in social situations & 4.28 & 0.68 & 85.52 \\
\hline 11 & $\begin{array}{l}\text { I encourage the expression of different points of view from } \\
\text { colleagues more than before }\end{array}$ & 4.22 & 0.65 & 84.48 \\
\hline 12 & I am better at listening to others & 4.34 & 0.62 & 86.90 \\
\hline 13 & I have higher ability in persuading others & 4.16 & 0.70 & 83.28 \\
\hline 14 & I have higher communication levels than others & 4.18 & 0.67 & 83.62 \\
\hline 15 & I helped my colleagues to be more motivated & 4.22 & 0.64 & 84.31 \\
\hline 16 & I resolve conflicts amongst my colleagues & 4.16 & 0.60 & 83.10 \\
\hline 17 & I have better at negotiation skills with others & 4.16 & 0.67 & 83.28 \\
\hline & Total & 4.18 & 0.65 & 83.74 \\
\hline
\end{tabular}

while item 23 (I ensure leadership succession as part of the school culture) ranked lowest.

To answer Question (3) of the study: What are the principals' perceptions of the extent to which their knowledge \& practices changed after completing the education leadership program at BTC?, the mean, standard deviation, percent and ranking of the study sample's responses to the impact of the program on the principals' knowledge and practices changed were calculated. Table 3 summarizes the obtained results.

Table 3 shows that $80.9 \%$ of the sample considers their study in the program positively affected their knowledge and practices (self-learning), with item 44 (develop a complete school vision, mission \& strategic plan which are aligned with the MOE ones) ranked highest, while item 40 perform professional presentations in English on leadership issues) ranked lowest.

To answer Question (4) of the study: What are the principals' perceptions of the extent to which their knowledge \& practices changes after completing the education leadership program at BTC affected their staff teaching and practices?, the means, standard deviations, percentages, and rankings of the study sample's responses to 
TABle 2: Descriptive statistics for Principals' Perceptions of the Change in their Leadership Styles and Practices to support their school development.

\begin{tabular}{l|l|} 
No. & Items \\
\hline 18 & I know more about the various leadership styles \\
20 & $\begin{array}{l}\text { I value the importance of developing a great amount of trust } \\
\text { among school staff }\end{array}$ \\
\hline 21 & $\begin{array}{l}\text { I focus on encouraging my staff to make better quality } \\
\text { decisions }\end{array}$ \\
\hline 22 & I utilize different resources of expertise available among staff \\
\hline 23 & I ensure leadership succession as part of the school culture \\
\hline 24 & I ensure sustainability of effective practices in the school \\
\hline 25 & I give control of some key operational decisions to my staff \\
\hline 26 & My staff assume better leadership responsibilities \\
\hline 27 & I encourage shared decision-making in my school \\
\hline 28 & I accept the outcomes of any shared decisions with my staff \\
\hline 33 & I provide constructive feedback to staff to help them in \\
\hline 34 & Ieveloping their leadership competencies \\
\hline 35 & I encourage my staff to express their viewpoints openly \\
\hline 36 & $\begin{array}{l}\text { I support students to practice leadership skills in school } \\
\text { activities }\end{array}$ \\
\hline 37 & $\begin{array}{l}\text { I promote using effective leadership skills to help my school to } \\
\text { achieve better QAA reports }\end{array}$ \\
\hline 38 & I encourage using effective leadership skills to help students to \\
\hline perform better academically
\end{tabular}

\begin{tabular}{|c|c|c|}
\hline Mean & Std. D & Percent \\
\hline 4.38 & 0.52 & 87.59 \\
\hline 4.41 & 0.62 & 88.10 \\
\hline 4.28 & 0.62 & 85.69 \\
\hline 4.20 & 0.66 & 83.97 \\
\hline 4.13 & 0.64 & 82.61 \\
\hline 4.31 & 0.61 & 86.21 \\
\hline 4.14 & 0.63 & 82.76 \\
\hline 4.27 & 0.60 & 85.34 \\
\hline 4.28 & 0.61 & 85.52 \\
\hline 4.22 & 0.66 & 84.31 \\
\hline 4.34 & 0.56 & 86.90 \\
\hline 4.43 & 0.58 & 88.62 \\
\hline 4.20 & 0.64 & 83.97 \\
\hline 4.41 & 0.61 & 88.28 \\
\hline 4.36 & 0.61 & 87.24 \\
\hline 4.37 & 0.64 & 87.30 \\
\hline 4.30 & 0.61 & 85.90 \\
\hline
\end{tabular}

the impact of the program modules on their performance was calculated. Table 4 summarizes the results.

Table 4 shows that $81.7 \%$ of the sample considers their study in the program positively affected their staff teaching and practices, with item 80 (use ICT in their classrooms as an innovative teaching and learning tool) ranked highest, while item 69 (become more engaged in school research activities) ranked lowest.

To answer Question (5) of the study: What are the principals' perceptions of the extent to which their knowledge \& practices changes after completing the education leadership program at BTC are embedded in their schools' routine?, the means, standard deviations, percentages, and rankings of the study sample's responses to the impact of the program modules on their performance was calculated. Table 5 summarizes the results.

Table 5 shows that $82.18 \%$ of the sample considers their study in the program positively affected embedding knowledge \& practice in school routines, with item 
TABle 3: Descriptive statistics for Principals' Perceptions of the extent to which knowledge \& practice changed (self-learning).

\begin{tabular}{|c|c|}
\hline No. & Items \\
\hline 39 & Write reflective essays on selected educational issues \\
\hline 40 & $\begin{array}{l}\text { Perform professional presentations in English on leadership } \\
\text { issues }\end{array}$ \\
\hline 41 & $\begin{array}{l}\text { Analyse my leadership roles in light of contemporary } \\
\text { leadership models }\end{array}$ \\
\hline 42 & $\begin{array}{l}\text { Utilize leadership theories to respond to reform issues in the } \\
\text { school context }\end{array}$ \\
\hline 43 & $\begin{array}{l}\text { Analyse the internal and external school environments using } \\
\text { specific techniques e.g. SWOT and Value chain }\end{array}$ \\
\hline 44 & $\begin{array}{l}\text { Develop a complete school vision, mission \& strategic plan } \\
\text { which are aligned with the MOE ones }\end{array}$ \\
\hline 45 & $\begin{array}{l}\text { Find innovative ways to improve my school's sustainable } \\
\text { competitive advantage }\end{array}$ \\
\hline 46 & Evaluate teachers' practices in relation to the school's vision \\
\hline 47 & $\begin{array}{l}\text { Understand the importance of research for improving learning } \\
\text { and teaching practices in school }\end{array}$ \\
\hline 48 & Learn more about various ways for analysing the curriculum \\
\hline 49 & $\begin{array}{l}\text { Learn more about my leadership role in the curriculum } \\
\text { innovation and development }\end{array}$ \\
\hline 50 & Learn about contemporary performance appraisal concepts \\
\hline 51 & $\begin{array}{l}\text { Improve my leadership knowledge and skills through visiting } \\
\text { other schools. }\end{array}$ \\
\hline 52 & $\begin{array}{l}\text { Prioritize the areas of concerns in my school that need to be } \\
\text { investigated through school research }\end{array}$ \\
\hline 53 & $\begin{array}{l}\text { Design quantitative and/or qualitative research tools to collect } \\
\text { data related to the school research }\end{array}$ \\
\hline 54 & $\begin{array}{l}\text { Analyse quantitative and/or qualitative data related to the } \\
\text { school research }\end{array}$ \\
\hline 55 & Analyse the factors that impact the students' learning \\
\hline 56 & $\begin{array}{l}\text { Understand learning theories to fulfil the quality assurance } \\
\text { (QAA) evaluation requirements for my school }\end{array}$ \\
\hline 57 & Understand my roles in leading home school relations \\
\hline 58 & $\begin{array}{l}\text { Deal efficiently with ethical and legal issues related to my } \\
\text { school context }\end{array}$ \\
\hline 59 & Deal ethically with my school staff. \\
\hline 60 & $\begin{array}{l}\text { Design professional development plan based on my training } \\
\text { staff needs }\end{array}$ \\
\hline 61 & $\begin{array}{l}\text { Integrate professional development activities in my school } \\
\text { strategic planning }\end{array}$ \\
\hline 62 & $\begin{array}{l}\text { Integrate technological tools to facilitate teaching and learning } \\
\text { process }\end{array}$ \\
\hline 63 & $\begin{array}{l}\text { Use technological tools to improve communication with } \\
\text { different stakeholders }\end{array}$ \\
\hline 64 & Integrate ICT usage in my school strategic planning \\
\hline 65 & Reflect on personal beliefs \\
\hline 66 & Improve my professional values \\
\hline
\end{tabular}

\begin{tabular}{|c|c|c|}
\hline Mean & Std. D & Percent \\
\hline 3.50 & 0.84 & 69.91 \\
\hline 3.12 & 1.08 & 62.43 \\
\hline 3.97 & 0.61 & 79.48 \\
\hline 4.06 & 0.55 & 81.21 \\
\hline 4.23 & 0.65 & 84.66 \\
\hline 4.34 & 0.60 & 86.72 \\
\hline 4.09 & 0.65 & 81.90 \\
\hline 4.15 & 0.68 & 82.93 \\
\hline 4.04 & 0.69 & 80.86 \\
\hline 3.93 & 0.69 & 78.62 \\
\hline 3.94 & 0.73 & 78.79 \\
\hline 4.17 & 0.71 & 83.45 \\
\hline 4.09 & 0.68 & 81.72 \\
\hline 3.96 & 0.74 & 79.13 \\
\hline 3.82 & 0.73 & 76.4 \\
\hline 3.85 & 0.82 & 77.07 \\
\hline 4.03 & 0.66 & 80.69 \\
\hline 3.97 & 0.61 & 79.48 \\
\hline 4.19 & 0.63 & 83.79 \\
\hline 4.09 & 0.68 & 81.72 \\
\hline 4.30 & 0.65 & 86.03 \\
\hline 4.29 & 0.63 & 85.86 \\
\hline 4.22 & 0.66 & 84.48 \\
\hline 4.28 & 0.71 & 85.52 \\
\hline 4.20 & 0.71 & 83.97 \\
\hline 4.22 & 0.70 & 84.48 \\
\hline 3.88 & 0.74 & 77.59 \\
\hline 4.27 & 0.73 & 85.34 \\
\hline 4.04 & 0.70 & 80.87 \\
\hline
\end{tabular}


TABle 4: Descriptive statistics for Principals' Perceptions of the effect on school staff.

\begin{tabular}{|c|c|}
\hline No. & Items \\
\hline 67 & $\begin{array}{l}\text { Have more important roles in the process of school strategic } \\
\text { planning }\end{array}$ \\
\hline 68 & $\begin{array}{l}\text { Translate school strategic plan objectives into their teaching } \\
\text { practices }\end{array}$ \\
\hline 69 & Become more engaged in school research activities \\
\hline 70 & Be more engaged in the curriculum innovations activities \\
\hline 71 & $\begin{array}{l}\text { Become more involved in their performance appraisal } \\
\text { processes }\end{array}$ \\
\hline 72 & $\begin{array}{l}\text { Benefit from implementing the ideas acquired from my } \\
\text { Educational Study Trip visits }\end{array}$ \\
\hline 73 & $\begin{array}{l}\text { Utilize the outcomes of School research to improve their } \\
\text { teaching practices }\end{array}$ \\
\hline 74 & $\begin{array}{l}\text { Design an action plan that integrates learning theories in the } \\
\text { school curriculum }\end{array}$ \\
\hline 75 & $\begin{array}{l}\text { Understand the effect of cognitive individual differences on } \\
\text { students' learning }\end{array}$ \\
\hline 76 & Offer innovative ways to communicate with students' families \\
\hline 77 & Become more aware of their ethical and legal duties \\
\hline 78 & $\begin{array}{l}\text { Improve their teaching practices through professional } \\
\text { development activities }\end{array}$ \\
\hline 79 & $\begin{array}{l}\text { Create a learning community in school that values lifelong } \\
\text { learning }\end{array}$ \\
\hline 80 & $\begin{array}{l}\text { Use ICT in their classrooms as an innovate teaching and } \\
\text { learning tool }\end{array}$ \\
\hline 81 & $\begin{array}{l}\text { Implement ICT to achieve the goals of 'King Hamad school of } \\
\text { the future' project }\end{array}$ \\
\hline 82 & Create a community of shared professional values \\
\hline
\end{tabular}

\begin{tabular}{|c|c|c|}
\hline Mean & Std. D & Percent \\
\hline 4.16 & 0.60 & 83.10 \\
\hline 4.22 & 0.62 & 84.48 \\
\hline 3.69 & 0.65 & 73.74 \\
\hline 3.87 & 0.67 & 77.41 \\
\hline 4.04 & 0.61 & 80.87 \\
\hline 4.18 & 0.65 & 83.62 \\
\hline 3.97 & 0.65 & 79.48 \\
\hline 3.82 & 0.76 & 76.35 \\
\hline 4.06 & 0.67 & 81.22 \\
\hline 4.03 & 0.65 & 80.70 \\
\hline 4.09 & 0.64 & 81.74 \\
\hline 4.20 & 0.64 & 83.97 \\
\hline 4.22 & 0.62 & 84.35 \\
\hline 4.31 & 0.70 & 86.21 \\
\hline 4.29 & 0.69 & 85.86 \\
\hline 4.21 & 0.67 & 84.14 \\
\hline 4.09 & 0.66 & 81.70 \\
\hline
\end{tabular}

83 (using strategic educational management planning) ranked highest, while item 85 (finding innovative ways to develop school curricula) ranked lowest.

To answer Question (6) of the study: What are the principals' [receptions of the extent to which their knowledge \& practices changes after completing the education leadership program at BTC affected their students' performance and school ranking?, the means, standard deviations, percentages, and rankings of the study sample's responses to the impact of the program modules on their performance was calculated. Table 6 summarizes the results. 
TABle 5: Descriptive statistics for Principals' Perceptions of the effect on embedding knowledge \& practice in school routine.

\begin{tabular}{|c|c|c|c|c|}
\hline No. & Items & Mean & Std. D & Percent \\
\hline 83 & Using strategic educational management planning & 4.29 & 0.63 & 85.86 \\
\hline 84 & $\begin{array}{l}\text { Using research as an important tool for solving teaching and } \\
\text { learning challenges }\end{array}$ & 3.94 & 0.65 & 78.79 \\
\hline 85 & Finding innovative ways to develop school curricula & 3.84 & 0.71 & 76.90 \\
\hline 86 & $\begin{array}{l}\text { Using contemporary performance appraisal approaches for } \\
\text { evaluating school staff }\end{array}$ & 4.15 & 0.59 & 82.93 \\
\hline 87 & $\begin{array}{l}\text { Applying teaching and learning practices acquired through the } \\
\text { Educational Study Trip visits }\end{array}$ & 3.97 & 0.69 & 79.48 \\
\hline 88 & $\begin{array}{l}\text { Introducing new teaching and learning ideas based on school } \\
\text { research }\end{array}$ & 3.90 & 0.68 & 77.93 \\
\hline 89 & $\begin{array}{l}\text { Raising awareness of cognitive individual differences among } \\
\text { learners }\end{array}$ & 4.03 & 0.60 & 80.53 \\
\hline 90 & $\begin{array}{l}\text { Establishing effective collaboration between families, school } \\
\text { and community }\end{array}$ & 4.19 & 0.60 & 83.79 \\
\hline 91 & Adhering to legal guidelines & 4.28 & 0.67 & 85.52 \\
\hline 92 & $\begin{array}{l}\text { Establishing continuous professional development activities } \\
\text { based on school needs }\end{array}$ & 4.22 & 0.65 & 84.35 \\
\hline 93 & $\begin{array}{l}\text { Engaging teachers in exchanging ideas in professional } \\
\text { development seminars }\end{array}$ & 4.27 & 0.65 & 85.39 \\
\hline \multirow[t]{2}{*}{94} & $\begin{array}{l}\text { Using ICT to facilitate the work flow of school activities and } \\
\text { processes }\end{array}$ & 4.23 & 0.72 & 84.70 \\
\hline & Total & 4.11 & 0.65 & 82.18 \\
\hline
\end{tabular}

Table 6 shows that $82.4 \%$ of the sample considers their study in the program positively affected students' performance, and school ranking, with item 95 (utilize strategic educational management planning to improve students' performance) ranked highest, while item 97 (leading curriculum innovation in my school to improving students' academic outcomes) ranked lowest.

To answer Question (7) of the study: What are the principals' perceptions of the extent to which their curriculum innovation, professional development, research, strategic management, staff appraisal, school community communication, homeschool relations, using ICT, improving students' learning and applying educational ethics skills are affected after completing the Education Leadership program at BTC?, the means, standard deviations, percentages, and rankings of the study sample's responses to the impact of the program modules on their performance was calculated. Table 7 summarizes the results.

According to table 7, the principals and assistant principals of the MOE schools in the Kingdom of Bahrain find that their study of the courses in the ELP at BTC has impacted their performance as school leaders. In addition, it is shown from table 7 that 
TABLE 6: Descriptive statistics for Principals' Perceptions of the effect on students' performance, and school ranking.

\begin{tabular}{|c|c|c|c|c|}
\hline No. & Items & Mean & Std. D & Percent \\
\hline 95 & $\begin{array}{l}\text { Utilize strategic educational management planning to improve } \\
\text { students' performance }\end{array}$ & 4.24 & 0.60 & 84.87 \\
\hline 96 & $\begin{array}{l}\text { Using research to overcome school challenges addressed in the } \\
\text { QAA reports }\end{array}$ & 3.87 & 0.70 & 77.41 \\
\hline 97 & $\begin{array}{l}\text { Leading curriculum innovation in my school to improving } \\
\text { students' academic outcomes }\end{array}$ & 3.87 & 0.71 & 77.39 \\
\hline 98 & $\begin{array}{l}\text { Using contemporary performance appraisal approaches in } \\
\text { evaluating teaching quality in my school }\end{array}$ & 4.05 & 0.57 & 81.00 \\
\hline 99 & $\begin{array}{l}\text { Applying the learned experiences acquired through the } \\
\text { Educational Study Trip helped to achieve higher QAA rank }\end{array}$ & 4.08 & 0.60 & 81.58 \\
\hline 100 & $\begin{array}{l}\text { Valuing scientific research as a way to enhance student } \\
\text { academic achievement }\end{array}$ & 3.99 & 0.60 & 79.82 \\
\hline 101 & $\begin{array}{l}\text { Applying of learning theories in improving students' learning } \\
\text { and success in my school }\end{array}$ & 4.11 & 0.63 & 82.24 \\
\hline 102 & $\begin{array}{l}\text { Improving home, school and community relations to positively } \\
\text { influence the students' performance }\end{array}$ & 4.21 & 0.54 & 84.17 \\
\hline 103 & $\begin{array}{l}\text { Improving students' behaviours as a result of better home, } \\
\text { school and community relations. }\end{array}$ & 4.19 & 0.56 & 83.79 \\
\hline 104 & $\begin{array}{l}\text { Improving students' behaviours as a result of respect of ethical } \\
\text { and legal rights respect }\end{array}$ & 4.17 & 0.64 & 83.48 \\
\hline 105 & $\begin{array}{l}\text { Engaging teachers in professional development activities } \\
\text { contributed to improving students' academic achievement }\end{array}$ & 4.22 & 0.59 & 84.48 \\
\hline 106 & $\begin{array}{l}\text { Engaging teachers in professional development activities } \\
\text { contributed to improving school ranking in the QAA. }\end{array}$ & 4.21 & 0.64 & 84.14 \\
\hline 107 & $\begin{array}{l}\text { Utilizing ICT in the classroom contributed to enhancing } \\
\text { students' academic achievement }\end{array}$ & 4.23 & 0.55 & 84.66 \\
\hline \multirow[t]{2}{*}{108} & $\begin{array}{l}\text { Utilizing ICT in the school help in achieving better QAA school } \\
\text { rank }\end{array}$ & 4.23 & 0.70 & 84.52 \\
\hline & Total & 4.12 & 0.62 & 82.40 \\
\hline
\end{tabular}

the school community communication module has impacted them the most, while the educational research module impacted them the least.

\section{Discussion of Findings}

Tables 1 to 6 show that: $83.8 \%$ of the sample considers their study in the ELP program positively affected their personal qualities, $85.9 \%$ considers their leadership styles and practices to support school development positively affected, 80.9\% considers their study in the program positively affected their knowledge and practices (self-learning), 81.7\% considers their staff teaching and practices (changing others) positively affected, $82.18 \%$ considers their study in the program positively affected 
TABle 7: Descriptive Statistics on the Impact of the Program Modules on the Principals' and Assistant Principals' Performance from their Perspective.

\begin{tabular}{|l|l|c|c|c|c|c|}
\hline No. & Module & \multicolumn{3}{|c|}{ Principals/assist. principals } & Rank \\
\hline 1 & Curriculum Innovation & Mean & Std. D & Percent & \\
\hline 2 & School Community communication & 3.97 & 0.68 & 79.36 & 9 \\
\hline 3 & Information \& Communication Technology & 4.40 & 0.61 & 87.93 & 1 \\
\hline 4 & Strategic Management & 4.12 & 0.73 & 82.48 & 6 \\
\hline 5 & Staff Appraisal & 4.22 & 0.62 & 84.51 & 2 \\
\hline 6 & Educational Research & 4.11 & 0.63 & 82.24 & 7 \\
\hline 7 & Professional Development & 3.90 & 0.69 & 78.06 & 10 \\
\hline 8 & Students' Learning & 4.18 & 0.65 & 83.60 & 4 \\
\hline 9 & Home School relations & 4.00 & 0.66 & 80.09 & 8 \\
\hline 10 & Ethics and Law & 4.16 & 0.60 & 83.25 & 5 \\
\hline
\end{tabular}

embedding knowledge \& practice in school routines, and $82.4 \%$ considers their students' performance, and school ranking (sustainability) positively affected.

The ELP program impacted school principals' leadership styles and practices the most $(85.9 \%)$, followed by their personal qualities $(83.8 \%)$ and the sustainability in students' performance and school rankings (82.4\%). These last two factors are the ultimate outcomes which both the Bahrain Quality Assurance Authority and the Ministry of Education give high priority to when evaluating schools and school principals.

The fact that the impact on the principals' and assistant principals' leadership styles and practices came first may be attributed to hat this topic is tackled directly and indirectly through many modules and activities in the program.

The school leaders placed self-learning last, this may be due to the fact that not all the covered materials in the program are relevant to their needs and challenges to lead their schools.

From table 7, the School Community communication module came in the first place as the most one that impacted the performance of the principals and assistant principals with a percentage of $87.93 \%$, while the Educational Research module came tenth with a percentage of $78.06 \%$. This indicates that the covered materials in some modules, especially of the educational research and curriculum innovations modules, need to be revised. We also suggest revising the activities and teaching strategies used in delivering such modules. The fact that education research module came in $10^{\text {th }}$ place may also be attributed to the fact that the majority of the program participants have had limited research skills prior to joining the program. 


\section{Conclusion}

The education leadership program offered by BTC to Bahrain government school principals and assistant principals positively affected their performance, from their perspectives. However, the program requirements need to be tuned to suit the purpose of improvement and alignment with the school leaders' needs, the Ministry of Education's expectations, and international best practices. We also recommend comparing our program impact results with the impact of other leaders' initial preparation programs in various educational systems.

\section{Acknowledgement}

This research paper is the product of a research grant project $(14 / 2015)$ that was approved and supported by the Deanship of Scientific Research at the University of Bahrain.

\section{References}

[1] Barber, M., Whelan, F., \& Clark, M. (2010). Capturing the leadership premium: How the world's top school systems are building leadership capacity for the future. London, UK: McKinsey \& Company

[2] Barton, L.T. (2013). Knowledge of effective educational leadership practices. International Journal of Leadership Preparation, 8(1), 93-102.

[3] Bush, T., Briggs, A., \& Middlewood, D. (2006). The impact of school leadership development: evidence from the 'new visions' program for early headship. Journal of In-Service Education, 32(2), 185-200. DOI:10.1080/13674580600650948

[4] Bush, T. (2009). Leadership development and school improvement: contemporary issues in leadership development. Educational review, 61 (4), 375-389.

[5] Cotton, K. (2003). Principals and student achievement: What the research says. Alexandria, VA: Association for Supervision and Curriculum Development.

[6] Darling-Hammond, L., LaPointe, M., Meyerson, D., Orr. M. T., \& Cohen, C. (2007). Preparing School Leaders for a Changing World: Lessons from Exemplary Leadership Development Programs. Stanford, CA: Stanford University, Stanford Educational Leadership Institute, downloaded from http://seli.stanford.edu or http://srnleads. org. on July $23,2014$. 
[7] Davis, S., Darling-Hammond, L., LaPointe, M., \& Meyerson, D. (2005). School leadership study: Developing successful principals. Stanford Educational Leadership Institute, Learning from Leadership, the Wallace Foundation.

[8] Fluckiger, B., Lovett, S. \& Dempster, N. (2014). Judging the quality of school leadership learning programs: an international search Journal of Professional Development in Education, 40(4), 561-575.

[9] Fullan, M. (2007). Change the terms for teacher learning. Journal of Staff Development; Oxford 28(3), 35-36.

[10] Leithwood, K. Duke, D. (1999). A century's quest to understanding school leadership. In J. Murphy \& L. Seashore (Eds.), Handbook of Research on Educational Administration. 2nd ed. (pp. 45-73). San Francisco: Jossey-Bass.

[11] Leithwood, K. \& Jantzi, D. (2006). Transformational school leadership for largescale reform: Effects on students, teachers, and their classroom practices. School Effectiveness and School Improvement, 17(2), 201-227.

[12] Leithwood, K., Seashore-Louis, K., Anderson, S., \& Wahlstrom, K. (2004). How leadership influences student learning (Learning from Leadership Project Executive Summary). New York: The Wallace Foundation.

[13] Marzano, R.J., Waters, T., \& McNulty, B.A. (2005). School leadership that works: From research to results. Alexandria, VA: Association for Supervision and Curriculum Development; and Aurora, CO: Mid-continent Research for Education and Learning.

[14] Nicolaidou, M., \& Petridou, A. (2011). Evaluation of CPD programs: challenges and implications for leader and leadership development. School Effectiveness and School Improvement: An International Journal of Research, Policy and Practice, 22(1), 5185.DOI:10.1080/09243453.2010.547344

[15] Osterman, K. F., \& Hafner, M. M. (2009). Curriculum in leadership preparation: Understanding where we have been in order to know where we might go. In M. D. Young, G. M. Crow, J. Murphy \& R. T. Ogawa (Eds.), Handbook of research on the education of school leaders (pp. 269-317). New York: Routledge

[16] Pont, B., Nusche, D., \& Hopkins, D. (2008). Improving School Leadership: Case Studies on System Leadership (Volume2). Paris, France: OECD.

[17] Silins, H.C., Mulford, W.R., \& Zarins, S. (2003). Organizational learning and school change. Educational Administration Quarterly, 38(5), 613-642.

[18] Williams, H.S. (2009). An evaluation of principal interns' performance on the interstate school leader licensure consortium standards. National Forum of Educational Administration and Supervision Journal, 26(4), 1-7. 
[19] Yan, W. \& Ehrich, L. (2009). Principal preparation and training: a look at China and its issues. International Journal of Educational Management, 23(1), 51-64. 